\title{
Karely, new variety of cut flower heliconia, suitable for the humid Mexican tropics
}

\author{
Ortiz-Curiel, Simitrio ${ }^{*}$; Avendaño-Arrazate Carlos H. ${ }^{1}$; Iracheta-Donjuan Leobardo ${ }^{1}$ \\ 1 Instituto Nacional de Investigaciones Forestales Agrícolas y Pecuarias-Campo Experimental Rosario Izapa. \\ Km. 18. Carretera Tapachula - Cacahoatán, Tuxtla Chico, Chiapas. G.P. 30870. \\ Correspondence: ortiz.simitrio@inifap.gob.mx
}

\begin{abstract}
Objective: To describe Heliconia uxpanapensis $\times$ Heliconia latispatha var. Karely, interspecific variety generated for cut flower based on commercial standards.

Design/Methodology/Approach: Interspecific hand pollination was carried out between H. uxpanapensis Gutiérrez Báez $\times$ H. latispatha Benth. The female parent is endemic to Mexico; it presents compact growth due to its pachymorphic rhizome, red and erect inflorescence, and bracts in distal position. H. latispatha grows expansively due to its leptomorphic rhizome, its inflorescence, composed of orange bracts, is erect and helical. The F1 hybrid was self-fertilized and produced viable seed. The mature zygotic embryos were germinated in vitro, the seedlings were acclimatized at six months and at ten months they were established in the field; Heliconia var. Karely was generated from this population.

Results: Karely variety is F2 product of the interspecific cross between $H$. uxpanapensis $\times$ H. latispatha, it presents a compact growth habit, erect inflorescence, bracts in distal position of orange color with red border. The inflorescence is clean and healthy. The postharvest half-life is 15 days.

Study Limitations/Implications: Karely must be cultivated under an agroforestry system in conditions of 20 to $30 \%$ shade for the adequate pigmentation of the bracts. In addition, it requires sandy-loam soil for proper development and growth of its inflorescence.

Findings/Conclusions: Karely has ideal characteristics for cut flower and meets the characteristics established by the market.
\end{abstract}

Keywords: Inflorescence, bract, cut flower.

Gitation: Ortiz-Curiel, S., AvendañoArrazate C. H., \& Iracheta-Donjuan L. (2022). Karely, new variety of cut flower heliconia, suitable for the humid Mexican tropics. Agro Productividad. https://doi.org/10.32854/agrop. v15i2.2161

Editor in Chief: Dr. Jorge Cadena Iñiguez

Received: October 22, 2021. Accepted: January 14, 2022. Published on-line: February 28, 2022.

Agro Productividad, 15(2). February. 2022. pp: 3-8.

This work is licensed under a Creative Commons Attribution-NonCommercial 4.0 International license.

\section{INTRODUCTION}

Heliconia are a group of tropical plants that include more than 220 species, which have ornamental aptitude due to their inflorescence of remarkable colors (Kress et al., 1999). Thirteen of these species inhabit the tropical rainforests of Mexico, still in wild condition (Ortiz-Curiel et al., 2015a); however, improved varieties are also cultivated in Mexico for cut flower with commercial aims, particularly for the domestic market.

The varieties that are grown are of small $(20 \mathrm{~cm})$ to large $(1.20 \mathrm{~m})$ inflorescence, of multiple shapes, colors and textures. They are cataloged among exotic flowers due to their varied colors and the strange shapes of their bracts (Ortiz-Curiel et al., 2015b); in addition, their market niche is almost exclusive for the luxury market (Baltazar-Bernal et al., 2011). 
Colombia is the main producer and exporter of heliconia at the global level, and although the specific amount of exports of heliconia is unknown, because in the nomenclature of foreign export they are grouped with foliage, the export flow in 2020 was for the amount of 590.8 million dollars FOB (cost of the merchandise in the country of origin, transport and exports rights) with growth higher than $3.6 \%$ annually in the last three years (Procolombia, 2021).

In Mexico, the states of Chiapas, Tabasco and Veracruz are the main producers of heliconia for cut flower (Grajales and Montejo, 2008; Saldaña, 2004; Linares-Gabriel et al., 2017); however, there is no statistical record that points at volume of sales at the national or international level. Only Baltazar-Bernal et al., (2011) documented that the local production is destined to the wholesale food market in Mexico City, place that concentrates and distributes to wholesalers in the country, and these to flower shops. It has also been documented that intermediaries are the ones that transport the flowers to the market in Mexico City.

At least 50 variables are cultivated in Mexico, which are found in the list of the Heliconia Society International (Brunner, 2005), agency that documented 1066 cultivars through the countries of Central and South America. Some cultivars that are grown in our country are scarcely competitive because the market is dynamic, changing and constantly seeks novelty and quality. The high price of the plant material of the new varieties of heliconia in the international market, as well as the expenditure for imports, are costs that few producers are willing to defray.

To contribute and stimulate the development of tropical flower growing, the National Institute of Agricultural and Livestock Forest Research (Instituto Nacional de Investigaciones Forestales Agricolas y Pecuarias, INIFAP) implemented the genetic improvement program from the collection of the native heliconia diversity (Ortiz-Guriel et al., 2015b). In that program, the first variety of heliconia was obtained through the different methodologies of genetic improvement, among them interspecific hybridization; this variety is associated to the commercial standard in heliconia such as size of inflorescence, color, shape and durability (Díaz et al., 2002). In this sense, the objective of this study is to describe Heliconia uxpanapensis $\times$ Heliconia latispatha var. Karely, variety that is apt for cut flower.

\section{MATERIALS AND METHODS}

In the year 2014, in the Heliconia germplasm bank from INIFAP-Experimental Field Rosario Izapa, interspecific manual pollination between two native species of Mexico, $H$. uxpanapensis Gutiérrez Báez $\times$ H. latispatha Benth, was carried out. The origin of the parents that gave rise to the Karely variety is listed in Table 1.

Table 1. Data of the accessions that originated the new variety of Karely heliconia.

\begin{tabular}{l|l|l|c|c|c}
\multicolumn{1}{c|}{ Code } & \multicolumn{1}{|c|}{ Species } & \multicolumn{1}{|c|}{ Origin } & $\begin{array}{c}\text { Latitude } \\
(\mathbf{N})\end{array}$ & $\begin{array}{c}\text { Longitude } \\
(\mathbf{O})\end{array}$ & $\begin{array}{c}\text { Altitude } \\
(\mathbf{m})\end{array}$ \\
\hline Uxp-10 & H. uxpanapensis Gutiérrez Báez & Veracruz & $17^{\circ} 15^{\prime}$ & $94^{\circ} 22^{\prime}$ & 82.0 \\
\hline Lat_an & H. latispatha Benth & Chiapas & $15^{\circ} 16^{\prime}$ & $92^{\circ} 42^{\prime}$ & 35.6 \\
\hline
\end{tabular}


Heliconia uxpanapensis was the female parent, which is endemic (Figure 1A). It presents pachymorphic rhizome and therefore is of cluster growth, red stem, it prospers in conditions of 80 to $90 \%$ of sun radiation, reaches a height of up to $5 \mathrm{~m}$, presents an erect inflorescence, large, with up to 15 red to purple bracts arranged in a distal position on a rachis moderately in zig-zag. For its part, H. latispatha, the male parent, presents leptomorphic rhizome, reason why it is highly invasive, it is of green stem, 1 to $2.5 \mathrm{~m}$, tolerates $100 \%$ sunlight; its inflorescence is erect, of small to medium size with up to 10 bracts, of orange color, thin and curved on the tip, located in a rachis in zig-zag and when they age, they adopt a spiral shape (Figure 1B).

The interspecific hybrid (Karely's parent) presents intermediate inheritance between H. uxpanapensis and H. latispatha, both in its vegetative and reproductive structures (Figure 1C). The rhizome is of intermediate growth between leptomorphic and pachymorphic, of brown color and thin stem; with erect inflorescence, distal although helical when it ages; it presents bracts of orange color on the outside and red on the inside; its lengthened bracts makes them similar to H. latispatha, while its height of up to $5 \mathrm{~m}$ and number of bracts of 11-15 makes it similar to H. uxpanapensis; its main distinction is that it flowers all year long.

In July 2018, auto-fertilization of the interspecific hybrid $H$. uxpanapensis $\times H$. latispatha was induced; with the help of fabric protectors, inflorescences were covered and seed was obtained to generate the F2. The F2 seed was sown in vitro through the technique described by Ortiz-Curiel et al. (2019) and seedlings were obtained. In January 2019 the seedlings were acclimatized in polystyrene trays of 128 cavities with transparent dome and a substrate with a proportion of 80:20 peat-agrolite $\mathrm{v} / \mathrm{v}$ was used. The acclimation was performed in a condition of $50 \%$ shade and relative moisture of $100 \%$ in the first 30 days. After 60 days of acclimation, the plants were changed to $20 \times 30 \mathrm{~cm}$ bags in $50-50 \%$ substrate of loamagrolite soil. In August 2019, in the Experimental Field Rosario Izapa, 90 plants were sown in sandy-loam soil, with $\mathrm{pH}$ of 6 , in shade intensity of $20 \%$, and under irrigation conditions. The flowering began in March 2020 and since that date the morphologic characterization
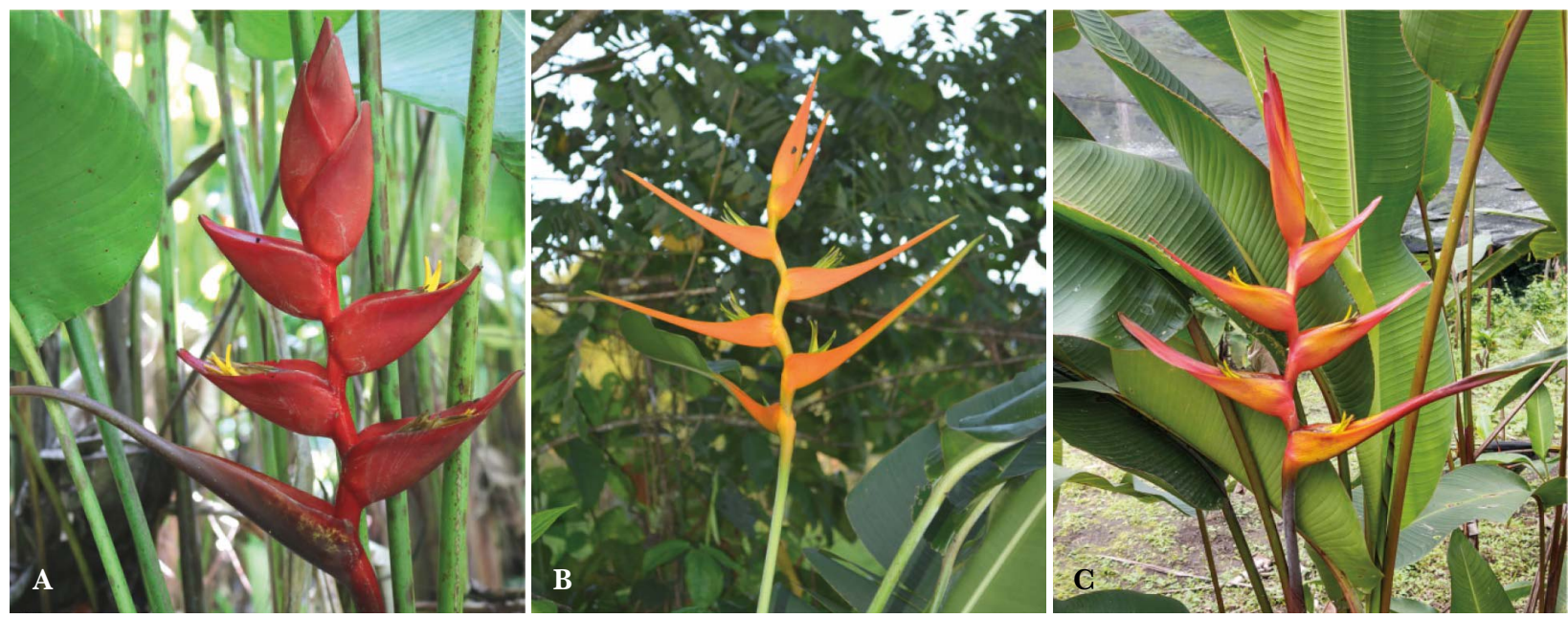

Figure 1. Parents of Heliconia var. Karely. A) H. uxpanapensis Gutiérrez Báez and B) H. latispatha Benth, and C) Interespecific hybrid $H$. uxpanapensis $\times$ H. latispatha. 
started, based on the descriptors suggested for the genus Heliconia by Avendaño et al. (2017). Later, the selection process began based on commercial standards for cut flower, where the H-67-9 plant was selected in the end. This plant is propagated asexually to maintain the genetic identity and a plot was established for morphologic characterization, agronomic evaluation, and shelf life in the conditions referred before. Finally, this genotype was called Karely variety.

\section{RESULTS AND DISCUSSION}

\section{Karely varietal description}

The plant is of medium to high growth habit, of cluster growth (Figure 2A), with erect inflorescence and bracts in distal position. These morphological traits are similar to $H$. uxpanapensis, except in its inflorescence color, since Karely presents rachis and bracts of orange color (Figure 2B), while H. uxpanapensis presents red inflorescence. As the Karely inflorescence ages the orange color of the bracts gets more intense, becoming red. A special characteristic of Karely is that its bracts are healthy and do not get dirty with the rainwater that they store. In addition to the characterization studies, the first trials on its post-harvest life showed that it has a mean durability of 15 days with slight indications of senescence under conditions of $27^{\circ} \mathrm{C}$ and $82 \%$ of relative humidity.

Table 2 presents the morphological descriptors of the Karely variety. The traits of this variety described suggest that it is adequate for cut flower. Its inflorescence, as well as the phylotaxy of its bracts, is an attribute that facilitates the arrangements of the inflorescences in the package and avoids scarring or bruising, relevant characteristic of commercial varieties such as Heliconia wagneriana, H. bihai, $H$. stricta, $H$. ortotricha, and $H$. caribaea. In this sense, it is apt both for national and international trade. The thickness of the stem in the cutting zone, of $2.5 \mathrm{~cm} \times 4.2 \mathrm{~cm}$ compared to $3.4 \mathrm{~cm} \times 4.6 \mathrm{~cm}$ of $H$. caribaea, represents lower weight per volume if it is considered that each flower stem is up to $1.2 \mathrm{~m}$ long; this finally translates into a cost reduction for transport.
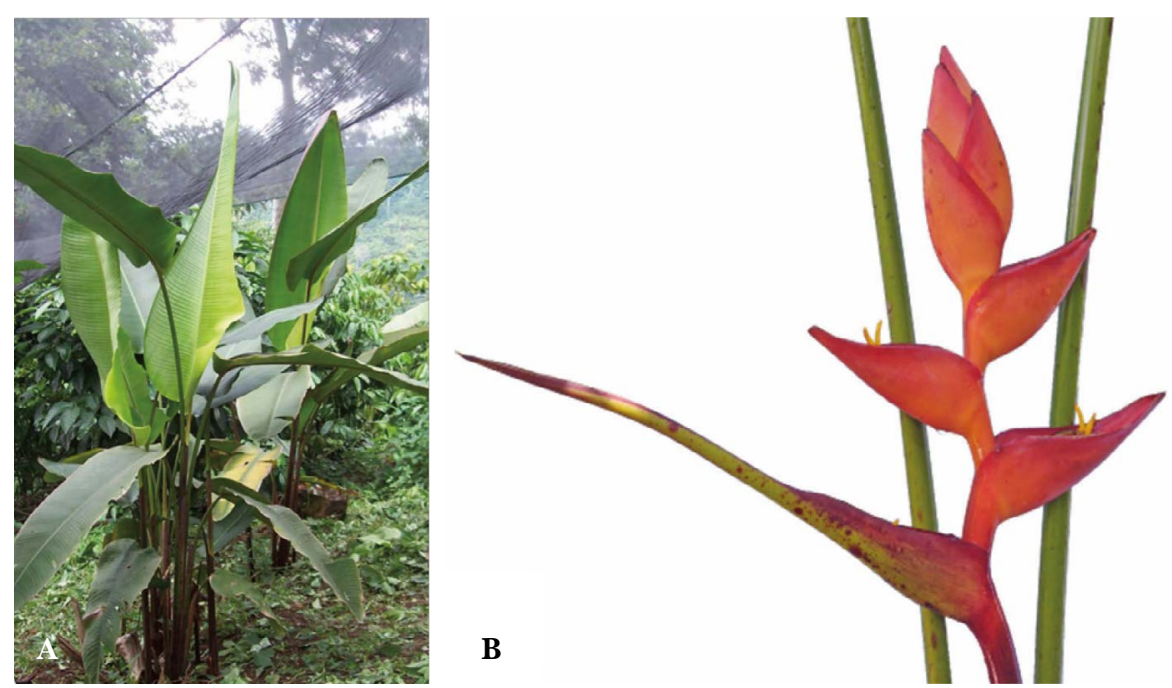

Figure 2. Heliconia uxpanapensis Gutiérrez $\times$ H. latispatha variedad Karely. A) Plant before flowering, and B) Inflorescence. 
Table 2. Morphological descriptors for the genus Heliconia with which the Karely variety was described (Avendaño et al., 2017).

\begin{tabular}{|c|c|c|c|}
\hline Number & Character & Character/Mean of Heliconia Karely variety & Example Heliconia uxpanapensis \\
\hline 1 & Gulm growth & Compact & \\
\hline 2 & Type of rhizome & Pachymorph & \\
\hline 3 & Plant growth & Musoide & \\
\hline 4 & Plant length $(\mathrm{cm})$ & 277.0 & \\
\hline 5 & Pseudostem length $(\mathrm{cm})$ & 151.3 & \\
\hline 6 & Pseudostem width $60(\mathrm{~mm})$ & 48.9 & \\
\hline 7 & Pseudostem thickness $60(\mathrm{~mm})$ & 28.9 & \\
\hline 8 & Pseudostem colour & Green & Reed \\
\hline 9 & Pseudostem shape & Oval & \\
\hline 10 & Pseudostem pubescence & Glabrous & \\
\hline 11 & Pseudostem length ratio and leaf length & 1.13 & \\
\hline 12 & Wax in pseudostem & Absence & \\
\hline 13 & Limb edge & Entire & \\
\hline 14 & Limb ondulation & Absence & \\
\hline 15 & Limb's base shape & Alternate & \\
\hline 16 & Limb's apices shape & Acute & \\
\hline 17 & Limb length $(\mathrm{cm})$ & 125.7 & \\
\hline 18 & Limb width $(\mathrm{cm})$ & 38.3 & \\
\hline 19 & Limb length-to-width ratio & 3.2 & \\
\hline 20 & Limb color & Light green & \\
\hline 21 & Leaves arrangement & Alternate & \\
\hline 22 & Leaves present & 4 & \\
\hline 23 & Limb's petiole length $(\mathrm{cm})$ & 139.0 & \\
\hline 24 & Petiole consistency & Full & \\
\hline 25 & Leaf length $(\mathrm{cm})$ & 264.7 & \\
\hline 26 & Wax in limb & Absence & \\
\hline 27 & Type of leaf venation & Highly visible & \\
\hline 28 & Leaf growth & Outwards (salient) & \\
\hline 28 & Leaf symmetry & Symmetric & \\
\hline 30 & Inflorescence growth & Erected & \\
\hline 31 & Inflorescence length $(\mathrm{cm})$ & 55.0 & \\
\hline 32 & Inflorescence width $(\mathrm{cm})$ & 25.0 & \\
\hline 33 & inflorescence length-to-width ratio & 2.2 & \\
\hline 34 & Rachis shape & Undulate & \\
\hline 35 & Rachis width (cm) & 17.4 & \\
\hline 36 & Rachis thickness (cm) & 18.3 & \\
\hline 37 & Presence of pubescence & Glabrous & \\
\hline 38 & Open bracts & 12.0 & \\
\hline 39 & Second bract length $(\mathrm{cm})$ & 12.0 & \\
\hline 40 & Second bract width (mm) & 4.3 & \\
\hline 41 & Second bract thickness $(\mathrm{mm})$ & 25.0 & \\
\hline 42 & Bracts arrangement & Distichous & \\
\hline 43 & Bracts color & Orange & Reed (5R3/10) \\
\hline 44 & Bract shape & Boat-like & \\
\hline 45 & Rachis colouring & Orange & Reed (5R3/10) \\
\hline 46 & Type of inflorescence & Erected & \\
\hline 47 & Sepals colour & Yellow & \\
\hline 48 & Pedicel color & White & \\
\hline 49 & Sepal length of the most flourished flower (mm) & 51.6 & \\
\hline 50 & Most flourished flower width (mm) & 6.1 & \\
\hline 51 & Most flourished flower thickness (mm) & 5.3 & \\
\hline 52 & Pedicel length $(\mathrm{mm})$ & 18.5 & \\
\hline 53 & Pedicel width $(\mathrm{cm})$ & 5.3 & \\
\hline 54 & Ovary color & Yellow & \\
\hline
\end{tabular}

*Obtained from: Munsell Plant Tissue Color Book. 
Due to its origin, the Karely variety is favorable for the producing zone of heliconia under agro-forestry management, in association with cacao or timber-producing trees, since 20 to 30\% shade is necessary for an adequate tonality and quality of inflorescence. The documentation that supports the Karely variety was delivered to Mexico's National Seeds Inspection and Certification Service (Servicio Nacional de Inspección y Certificación de Semillas en México, SNICS-SADER) for its registry in the National Catalog of Varieties and to obtain the corresponding Breeder Title. It should be mentioned that the plant material for multiplication is protected in the INIFAP-Experimental Field Rosario Izapa.

\section{CONGLUSIONS}

Heliconia var. Karely was described, destined for cut flower. Its morphological characteristics of inflorescence such as shape, size, weight, inflorescence color and durability are attributes of commercial importance.

\section{ACKNOWLEDGEMENTS}

We thank the National Institute of Forest, Agricultural and Livestock Studies for financing the project "New varieties of heliconia for the ornamental use in agro-forestry systems number 14114734385".

\section{REFERENCES}

Avendaño-Arrazate, G.H., Arrazate-Argueta, J.A., Ortiz-Curiel, S., Moreno-Pérez, E., Iracheta-Donjuan, L., Reyes-López, D., Grajales-Solís, M., Martínez-Bolaños, M. and Cortés-Cruz, M. (2017). Morphological characterization in wild species of heliconias (Heliconia spp) in Mexico. American Journal of Plant Sciences 8, 1210-1223. https://doi.org/10.4236/ajps.2017.86080

Baltazar-Bernal, O., Zavala-Ruiz, J. y Hernández-Nataren, S. de J. (2011). Producción comercial de heliconias. Colegio de Postgraduados. Montecillo, Texcoco. 63p.

Brunner, B. (2005). The Heliconia check list and register. Heliconia Society International, Vol 12:36p.

Grajales-Solís, M. y Montejo-Rodríguez F.S. (2008). Sistemas agroforestales con maderables y ornamentales en caco en el soconusco, Chiapas, Instituto nacional de Investigaciones Forestales Agrícolas y Pecuarias. Centro de Investigación Regional Pacífico Sur. Tuxtla Chico, Chiapas 22p.

Kress, W.J., Betancur, J., \& Echeverry, B. (1999). Heliconias-Llamaradas de la Selva Colombiana. Bogotá, Colombia: Cristina Uribe Editores.

Linares-Gabriel, A., Velasco-Velasco, J., Rodríguez-Orozco, N., Tinoco-Alfaro, C.A., Hernández-Chontal M.A. y López-Collado G.J. (2017). Comercialización de heliconias (Heliconia L.) en Acayucan, Veracruz, México. Agroproductividad 10:56-61.

Ortiz-Curiel, S., Avendaño-Arrazate, C.H., Olivera de los Santos, A., Grajales-Solís, M., Canul-Ku, J., CortésCruz, M. y Iracheta-Donjuan, L. (2015a). Heliconia L.: Género subutilizado en México. Agroproductividad 8: 51-59

Ortiz-Curiel, S., Iracheta-Donjuan L., Grajales-Solis, M., Avendaño- Arrazate. C.H., Canul-Ku, J., CortésCruz M. y Olivera de los Santos, A. (2015b). Biología floral de heliconias de México. INIFAP. Centro de Investigación Regional Pacífico Sur. Campo Experimental Rosario Izapa. Folleto técnico Número 38, Tuxtla Chico, Chiapas, México. 33 p.

Ortiz-Curiel, S., Iracheta-Donjuan, L., Carrillo-Castañeda, G.; Avendaño-Arrazate, C. H. y GálvezMarroquín, L. A. (2018). Sacarosa y carbón activado in vitro determinan la germinación de embriones cigóticos de Heliconia L. Agroproductividad 11:109-115.

Procolombia, 2021. Exportaciones, turismo, inversión marca país. https://www.colombiatrade.com.co/ herramientas-del-exportador/estadisticas-de-comercio-exterior/informe-general-de-exportaciones-0 consultado enero 2022.

Saldaña y Hernández, M. I. (2004). Heliconias: Belleza y alternativa económica para Tabasco. En Revista Diálogos 16, Consejo de Ciencia y Tecnología del Estado de Tabasco. pp. 14-18. disponible en: http:// www.ccytet.gob.mx/Dialogos/Dialogos/PDF/dialogos16.pdf 